University of Nebraska - Lincoln

DigitalCommons@University of Nebraska - Lincoln

Reclassification of Subspecies of Acidovorax avenae as $A$. Avenae (Manns 1905) emend., A. cattleyae (Pavarino, 1911)comb.nov., A. citrulli Schaad et al.,1978)comb.nov., and proposal of $A$. oryzae sp. nov.

\author{
Norman Schaad \\ USDA-ARS \\ Elena Postnikova \\ USDA-ARS \\ Aaron Sechler \\ USDA-ARS \\ Larry E. Claflin \\ Kansas State University \\ Anne K. Vidaver \\ University of Nebraska-Lincoln, avidaver1@unl.edu

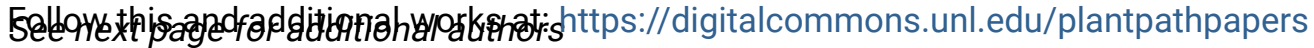 \\ Part of the Plant Pathology Commons
}

Schaad, Norman; Postnikova, Elena; Sechler, Aaron; Claflin, Larry E.; Vidaver, Anne K.; Jones, Jeffrey B.; Agarkova, Irina V.; Ignatov, Alexander; Dickstein, Ellen; and Ramundo, Bruce A., "Reclassification of Subspecies of Acidovorax avenae as A. Avenae (Manns 1905) emend., A. cattleyae (Pavarino, 1911)comb.nov., A. citrulli Schaad et al.,1978)comb.nov., and proposal of $A$. oryzae sp. nov." (2008). Papers in Plant Pathology. 133.

https://digitalcommons.unl.edu/plantpathpapers/133

This Article is brought to you for free and open access by the Plant Pathology Department at DigitalCommons@University of Nebraska - Lincoln. It has been accepted for inclusion in Papers in Plant Pathology by an authorized administrator of DigitalCommons@University of Nebraska - Lincoln. 


\section{Authors}

Norman Schaad, Elena Postnikova, Aaron Sechler, Larry E. Claflin, Anne K. Vidaver, Jeffrey B. Jones, Irina V. Agarkova, Alexander Ignatov, Ellen Dickstein, and Bruce A. Ramundo 


\title{
Reclassification of subspecies of Acidovorax avenae as $A$. Avenae (Manns 1905) emend., A. cattleyae (Pavarino, 1911) comb. nov., $A$. citrulli Schaad et al., 1978) comb. nov., and proposal of $A$. oryzae sp. nov.
}

\author{
Norman W. Schaad ${ }^{\mathrm{a}, *, 1}$, Elena Postnikova ${ }^{\mathrm{a}, 1}$, Aaron Sechler ${ }^{\mathrm{a}}$, Larry E. Claflin ${ }^{\mathrm{b}}$, \\ Anne K. Vidaver ${ }^{\mathrm{c}}$, Jeffrey B. Jones ${ }^{\mathrm{d}}$, Irina Agarkova ${ }^{\mathrm{c}}$, Alexander Ignatov ${ }^{\mathrm{e}}$, \\ Ellen Dickstein ${ }^{\mathrm{d}}$, Bruce A. Ramundo \\ a ARS-USDA, Foreign Disease-Weed Science Research Unit, 1301 Ditto Avenue, Ft. Detrick, MD 21702, USA \\ ${ }^{\mathrm{b}}$ Department of Plant Pathology, Kansas State University, Manhattan, KS, USA \\ ${ }^{\mathrm{c}}$ Department of Plant Pathology, University of Nebraska, Lincoln, NB, USA \\ ${ }^{\mathrm{d}}$ Department of Plant Pathology, University of Florida, USA \\ "Center "Bioengineering" RAS, Moscow, Russia
}

\begin{abstract}
The bacterium Acidovorax avenae causes disease in a wide range of economically important monocotyledonous and dicotyledonous plants, including corn, rice, watermelon, anthurium, and orchids. Genotypic and phenotypic relatedness among strains of phytopathogenic A. avenae subsp. avenae, A. avenae subsp. citrulli, A. avenae subsp. cattleyae and A. konjaci, as well as all other Acidovorax species, including A. facilis, the type strain of Acidovorax, was determined. The $16 \mathrm{~s}$ rDNA sequencing confirmed previous studies showing the environmental species to be very distant from the phytopathogenic species. DNA/DNA reassociation assays on the different strains of $A$. avenae revealed four (A, B, C, and D) distinct genotypes. Taxon A included six A. avenae subsp. avenae strains from corn that had a mean reciprocal similarity of $81 \%$; taxon B included six $A$. avenae subsp. avenae strains from rice that had a mean reciprocal similarity of $97 \%$; taxon C contained $11 \mathrm{~A}$. avenae subsp. citrulli strains from cucurbits (cantaloupe, watermelon, and pumpkin) that had a mean reciprocal similarity of $88 \%$, and taxon D contained four $A$. avenae subsp. cattleyae strains from orchids that had a mean similarity of $98 \%$. The mean reciprocal relatedness between taxa A, B, $\mathrm{C}$, and D was less than $70 \%$. Sequence analysis of $16 \mathrm{~S}$ rDNA and the $16 \mathrm{~S}-23 \mathrm{~S}$ rDNA internally transcribed spacer region, as well as AFLP analysis, revealed the same four taxa. All four were easily differentiated phenotypically from each other and from all other recognized Acidovorax species. Strains of A. avenae did not contain 3-hydroxyoctanoic acid, which was found in all other species. On the basis of these and previous genetic and phenotypic results, we propose an emendation of the species A. avenae. A. avenae subsp. citrulli (C strains) and A. avenae subsp. cattleyae (D strains) should be elevated to species rank as $A$. citrulli and $A$. cattleyae, respectively. We further propose a new taxon for the B strains, A. oryzae sp. nov. with FC-143 ${ }^{\mathrm{T}}=\mathrm{ICPB} 30003^{\mathrm{T}}=\mathrm{ICMP} 3960^{\mathrm{T}}=\mathrm{ATCC} 19882^{\mathrm{T}}$ as the type strain.
\end{abstract} Published by Elsevier GmbH.

Keywords: Acidovorax; Taxonomy; 16S and ITS sequencing; AFLP; Phenotypic tests; DNA/DNA reassociation; Emendation

\footnotetext{
*Corresponding author.

E-mail address: norman.schaad@ars.usda.gov (N.W. Schaad).

${ }^{1}$ Authors contributed equally to this work.
} 


\section{Introduction}

Acidovorax avenae subsp. avenae (Pseudomonas avenae) and $A$. avenae subsp. citrulli (synonymous with $P$. pseudoalcaligenes subsp. citrulli) have emerged worldwide as serious pathogens on corn (Zea mays L.) [40] and watermelon (Citrullus lanatus (Thunb.) Matsumura and Nakai) [42], respectively. Pseudomonas avenae, originally described in 1909 as the causal agent of leaf blight of oats (Avenae sativa L.) [31], causes disease under conditions of high rainfall and high temperatures in numerous species of the family Graminaceae, including wheat (Triticum aestivum L.), finger millet (Eleusine coracana (L.) Gaertn.), Italian millet (Setaria italica (L.) Beauv.), pearl millet (Pennisetum glaucum (L.) R. Br.), and proso millet (Panicum miliaceum L.) [4,9,32,33]. Additional hosts include tea (Thea sinensis L.), barley (Hordeum vulgare L.), mountain brome (Bromus carinatus Hook. \& Arn.), rescue grass (B. catharticus Vahl), vasey grass (Paspalum urvillei Steud.), teosinte (Zea mexicana (Schrad.) Kuntze), and sugarcane (Saccharum officinarum L.) $[2,13,17,49,50]$. P. alboprecipitans, a pathogen of foxtail (Chaetochloa lutescens (Weigel) Stuntz) [36], was later shown to be synonymous with the oats and corn pathogen, P. avenae [40]. Additionally, the red stripe disease of sugarcane caused by $P$. rubrilineans [17] was shown to be synonymous with $P$. avenae [35]. More recently $A$. avenae subsp. avenae has emerged as a serious pathogen of rice (Oryzae sativa L.) $[16,24,26,27,34]$. The causal agent of bacterial stripe of rice also has been referred to as " $[P$.] setariae" [14] and $P$. panici [34], however, neither epithet has been validly published [56]. A pathogen of orchids (Cattleya, Dendrobium, Oncidium, and Phalaenopsis), P. cattleyae, was described in 1946 [1]. A pathogen of konjac (Amorphophallus konjac K. Koch.), A. konjaci, was described in 1983 [15]. All of these phytopathogenic bacteria were described previously as a heterogenous group of non-fluorescent, oxidase positive pseudomonads, which accumulated poly- $\beta$-hydroxybutyrate (PHB) and utilized D-arabinose [38].

Schaad et al. [41] described a non-fluorescent pseudomonad as the causal agent of a seedling blight of watermelon. The bacterium differed phenotypically from other known plant pathogenic pseudomonads and was classified as $P$. pseudoalcaligenes subsp. citrulli [41]. Later, Wall and Santos determined that the same organism caused a disease referred to as watermelon fruit blotch of mature watermelon fruit [42]. Additional hosts of A. avenae subsp. citrulli include melon/ cantaloupe (Cucumis melo L. subsp. melo var. cantalupensis Naudin), cucumber (Cucumis sativus L.) [41], and pumpkin (Cucurbita pepo L.) [28]. The above nonfluorescent phytopathogenic pseudomonads together with $P$. pseudoalcaligenes subsp. cattleyae [1] and $P$. pseudoalcaligenes subsp. konjaci [15] were all shown to be part of the "acidovorans" DNA-rRNA homology group [7].

Based on DNA/DNA and DNA-rRNA homologies [5] and phenotypic assays, Willems et al. [55] proposed that the above "generically misnamed phytopathogenic pseudomonads" be transferred to the newly proposed genus Acidovorax [54]. Strains of $P$. avenae $[P$. rubrilineans $]$ from corn, sugar cane, Indian shot (Canna indica), teosinte, finger millet, and "P. setariae" from rice were all classified as $A$. avenae subsp. avenae. Strains of $P$. pseudoalcaligenes subsp. citrulli from Cucurbitaceae hosts were classified as $A$. avenae subsp. citrulli; strains of $P$. cattleyae from orchids were renamed as $A$. avenae subsp. cattleyae; and strains of $P$. pseudoalcaligenes subsp. konjaci [15] from konjac were classified as $A$. konjaci [55]. Recently two new phytopathogenic species of Acidovorax, A. anthurii on anthurium (Anthurium palmatum (L.) G. Don) [11] and A. valerianellae on lambs' lettuce (Valerianella locusta (L.) Lat.) [12], as well as a denitrifying species, A. caeni from activated sludge [18], have been described.

The purpose of this study was to re-evaluate the phylogenetic relatedness among the above phytopathogenic $A$. avenae strains and between $A$. avenae and the phytopathogenic A. konjaci, $A$. anthurii, and A. valerianellae. A polyphasic taxonomic study revealed considerable differences among the different subspecies of A. avenae and between the other species of Acidovorax. Therefore, we propose a new species, $A$. oryzae for the rice strains of $A$. avenae. We also propose $A$. avenae subsp. citrulli and $A$. avenae subsp. cattleyae be elevated to species rank as $A$. citrulli comb. nov. and $A$. cattleyae comb. nov.

\section{Materials and methods}

\section{Source of strains and confirmation of identity}

All the strains used in this study were obtained from the International Collection of Phytopathogenic Bacteria (ICPB) maintained at the USDA, ARS Foreign DiseaseWeed Science Research Unit (FDWSRU), Fort Detrick, MD or from other recognized culture collections (Table S-1). Each culture was streaked onto yeast extract-dextrose $\mathrm{CaCO}_{3}$ (YDC) agar [23] and beigetan colored, transparent, round, non-mucoid, convex colonies were retained. Cultures were maintained on YDC slants at room temperature and also archived at $-80^{\circ} \mathrm{C}[38]$.

\section{Pathogenicity}

Pathogenicity was determined for all A. avenae strains by inoculating 2-3 plants each of corn (cv. 'Iochief'), 
rice (cv. 'Nortai'), watermelon (cv. 'Charleston Grey'), or orchid (Phalaenopsis sp., Dendrobium sp., and Cattleya sp.). Additionally, wheat (cv. 'Anza') was included in pathogenicity tests for $A$. avenae strains. Strains of A. konjaci, A. anthurii, and A. valerianellae were not tested. Bacteria were grown overnight in $5 \mathrm{ml}$ of liquid nutrient broth (Difco, Detroit, MI) or nutrient broth yeast extract (NBY) medium [52] on a rotary shaker and the optical density was adjusted to 0.1 at $600 \mathrm{~nm}$. After diluting the suspension 1:100 in water, the growing points of 2-3 leaf-stage sweet corn and rice seedlings were injected using a 26-gauge needle and syringe. For watermelon, cotyledons of seedlings were infiltrated with the same suspension using the blunt end of a $2 \mathrm{ml}$ disposable syringe. Sterile water was included as a negative control. All seedlings were incubated in a lighted dew chamber (Percival Scientific, Inc. model I-60 DLM, Perry, IA 50220) at $30^{\circ} \mathrm{C} / 25^{\circ} \mathrm{C}$ day/night (12 h) and results were recorded after 10 days. For orchids, three to four sites of two new fully expanded leaves of flowering plants were infiltrated with inoculum using a 26-gauge needle and syringe and placed into a dew chamber at $27^{\circ} \mathrm{C} / 28^{\circ} \mathrm{C}$ day/night for 21 days.

\section{DNA preparation and DNA/DNA reassociation assays}

DNA was extracted by a modified lysozyme, phenol/ chloroform/ isoamyl alcohol method [43] and sheared using a French pressure cell (Spectronic Unicam, Rochester, NY), as described previously [43]. The purity and concentration of DNA was determined by measuring the 260/280 ratio using a "SmartSpec 3000" (Bio Rad, Richmond, CA) and only preparations with $260 / 280$ ratios of 1.8 or greater were included. All samples were adjusted to $200 \mathrm{ng} / \mu \mathrm{l}$ and stored at $-20^{\circ} \mathrm{C}$. The DNA/DNA reassociation assays were carried out using the S1 nuclease protocol [22], as described previously $[43,44]$. The probe and target DNA were reassociated at $71^{\circ} \mathrm{C}$ for $23 \mathrm{~h}$ in the presence of $22.7 \%$ formamide. For every one percent formamide, the temperature can be decreased by $0.6^{\circ} \mathrm{C}$ [22]. Using $22.7 \%$ formamide equated to reassociation at $84-85^{\circ} \mathrm{C}$ in the absence of formamide $\left(T_{\mathrm{m}}=98.6-15^{\circ} \mathrm{C}=\right.$ $83.6^{\circ} \mathrm{C}$ ) for $A$. avenae DNA with an average $\mathrm{mol} \%$ $\mathrm{G}+\mathrm{C}$ value of $72.2 \%$ [40]. Each reaction was repeated 3-5 times. The following phytopathogenic strains of Acidovorax from corn, $\mathrm{FC}-320^{\mathrm{T}}$ and 371 ; rice, $\mathrm{FC}-143^{\mathrm{T}}$; tea, FC-501; watermelon, FC-247 ${ }^{\mathrm{T}}$ and 513; konjac, FC-321 ${ }^{\mathrm{T}}$; orchid, FC-502; anthurium, CFBP $3232^{\mathrm{T}}$; lambs' lettuce, CFBP $4730^{\mathrm{T}}$; finger millet, FC-500; and non-phytopathogenic $A$. facilis $\mathrm{FC}-208^{\mathrm{T}}$, were labeled for DNA/DNA reassociation assays. Data for $A$. temperans, $A$. delafieldii, and $A$. defluvii were taken from Schulze et al. [45].

\section{AFLP}

The AFLP procedure was carried out as described previously [44]. Briefly, an AFLP template was prepared for PCR using a combination of MseI and EcoRI restriction endonucleases. Selective amplification was performed with $M s e I+C$ (5'-GAT GAG TCC TGA GTA AC- $\left.3^{\prime}\right)$ and $E c o$ RI +0 (5'-GAC TGC GTA CCA ATT C-3') primers. The EcoRI +0 primer had an infrared fluorescent dye IRDye 700 (Li-Cor Inc., Lincoln, NE). The separation of amplified products was performed on a $6.5 \%$ polyacrylamide gel using a LI-COR Long ReadIR ${ }^{\mathrm{TM}}$ DNA Sequencer (LI-COR model 4200) and electrophoresis data were automatically collected and simultaneously recorded during the run. The data were analyzed with GelCompar (v. 4.2) software (Applied Maths, Kortrijk, Belgium) and dendrograms were generated using the unweighted pair group method with averages (UPGMA). Strains of $A$. anthurii and $A$. valerianellae were not included in the AFLP analysis.

\section{Phenotypic characters}

Cells were grown overnight in liquid NBY shake cultures unless stated otherwise. Arginine dihydrolase activity [19] was determined at 28 and $37^{\circ} \mathrm{C}$. Lipase activity, starch hydrolysis, and PHB accumulation were determined as described previously [23]. For the oxidase test, filter paper impregnated with a $1 \%(\mathrm{w} / \mathrm{v})$ solution of $p$-aminodimethylaniline oxalate (Difco, Detroit, $\mathrm{MI}$ ) was used [38]. Gelatin hydrolysis and reduction of nitrate to nitrite was tested as described previously [8]. Degradation of pectate was tested using Hildebrand's media at three $\mathrm{pH}$ levels [19]. Growth at 4 and $41^{\circ} \mathrm{C}$ was determined by liquid NBY shake cultures in a New Brunswick Scientific (Edison, NJ) Innova refrigerated incubator shaker with a temperature variance of $\pm 0.1^{\circ} \mathrm{C}$. The cultures were observed for growth after 3 and 10 days. Action on litmus milk was determined using reconstituted powdered skim milk, as described previously [8]. Acid production and utilization of carbohydrates were determined on Dye's medium $\mathrm{C}$ containing bromthymol blue and a $1 \%$ final carbon source concentration [38], modified as follows: an overnight culture was adjusted to $0.1 \mathrm{OD}_{600}$ then serially diluted ten-fold to $10^{-4}$ and $10 \mu \mathrm{l}$ was spotted into individual wells of a 24 well tissue culture plate containing $2 \mathrm{ml}$ of the carbon source medium. All tests were repeated twice and read after 7 and 14 days, unless stated otherwise. The type strain and several additional strains (Table S-1) of each recognized phytopathogenic species and subspecies of Acidovorax along with the type strain of the genus, A. facilis, were included. Results for the phylogenetically distant environmental species 
A. temperans, A. defluvii, and A. caeni were from Willems et al. [55], Schulze et al. [45], and Heylen et al. [18], respectively.

\section{Fatty acid analysis}

The procedures used to prepare, extract, and differentiate fatty acids by gas-liquid chromatography have been described previously [39]. The fatty acid profiles of $A$. facilis strains, and each phytopathogen, including the newly described $A$. anthurii and $A$. valerianellae, were compared with those in the Sherlock ${ }^{\mathbb{R}}$ Microbial Identification System MIDI database (MIDI, Inc., Newark, DE) and were used to determine the Euclidian distance to Acidovorax spp. Results for A. caeni were from Heylen et al. [18].

\section{S rDNA and 16S-23S rDNA internal transcribed spacer (ITS) region sequencing}

Direct sequencing of $16 \mathrm{~S}$ rDNAs was performed with the following primers: 27f-AGA GTT TGA TCA TGG CTC AG and 1488r-CGG TTA CCT TGT TAC GAC TTC ACC [3]. The 16S rDNAs of the following strains were sequenced: phytopathogenic $A$. avenae subsp. avenae from corn $\left(\mathrm{FC}-320^{\mathrm{T}}\right)$, rice $\left(\mathrm{FC}-143^{\mathrm{T}}\right.$ and 192), tea (FC-501), finger millet (FC-500), A. avenae subsp. citrulli from watermelon $\left(\mathrm{FC}-247^{\mathrm{T}}\right), A$. anthurii from anthurium (CFBP $3232^{\mathrm{T}}$ ), A. valerianellae from lambs' lettuce (CFBP $\left.4730^{\mathrm{T}}\right)$, and non-phytopathogenic strains of A. facilis $\left(\mathrm{FC}-208^{\mathrm{T}}\right)$ and Comamonas testosteroni (FC-418). Sequences of $A$. avenae subsp. cattleyae, A. temperans, A. konjaci, A. defluvii, A. delafieldii, and A. caeni were obtained from GenBank.

Sequencing of the ITS region was performed with the following primers: 1493f-AGT CGT AAC AAG GTA GCC GT and 23r-GTG CCA AGG CAT CCA CC, as previously described [29]. The following strains were used for ITS comparisons: A avenae $\mathrm{FC}-320^{\mathrm{T}}$, FC-371, FB-966, FC-179 (corn); FC-501, and FC-506 (tea); $\mathrm{FC}-143^{\mathrm{T}}$, FC-155, and $\mathrm{FC}-192$ (rice); $\mathrm{FC}-247^{\mathrm{T}}$ (watermelon), FC-356, and FC-526 (melon), FC-528 (pumpkin); FC-500 (finger millet); FC-502, and FC-509 (orchids); A. konjaci $\mathrm{FC}-321^{\mathrm{T}}$ (konjac); A. anthurii CFBP $3232^{\mathrm{T}}$ (anthurium); A. valerianellae $4730^{\mathrm{T}}$ (lambs' lettuce); and $A$. facilis $\mathrm{FC}-208^{\mathrm{T}}$ (soil). The PCR fragments of both regions were amplified, from DNA prepared as above for DNA/DNA reassociation assays, in a 9700 Sequence Detection System (Applied Biosystems Inc., Foster City, CA) with an initial denaturation at $94{ }^{\circ} \mathrm{C}$ for $2 \mathrm{~min}$, followed by 30 cycles of denaturation at $94{ }^{\circ} \mathrm{C}$ for $30 \mathrm{~s}$, annealing at $50{ }^{\circ} \mathrm{C}$ for $30 \mathrm{~s}$, and extension at $72^{\circ} \mathrm{C}$ for $45 \mathrm{~s}$. Final extension was performed at $72^{\circ} \mathrm{C}$ for $10 \mathrm{~min}$. Aliquots of amplified samples were analyzed on $2.0 \%$ agarose gels. The fragments were purified using a "Wizard DNA CleanUp System" (Catalog \# A7280, Promega, Madison, WI), according to the manufacturer's protocol, and sequenced with an Applied Biosystems model 310 sequencer and Big Dye Terminator cycle sequencing kit.

Sequences were analyzed with the Sequence Navigator 1.01 program (Applied Biosystems) and compared using the Gene Inspector $1.5 f$ program (Textco, Inc., Research Triangle Park, NC). Alignments were verified manually.

\section{Results}

\section{Pathogenicity}

All strains originating from rice were pathogenic to both rice and corn (Table S-2). In contrast, strains from corn were pathogenic to corn but not rice (Table S-2). Strain FB-965, originating from corn, was not pathogenic to corn, wheat, or rice. Corn strains differed by their reaction on wheat (data not shown): strains FC-179, FC-320, FB-966, and FC-371 were pathogenic, whereas strains FC-358, FC-369 were not. Rice strains were not pathogenic to wheat. All A. avenae subsp. citrulli strains were pathogenic to watermelon, but not to corn. Orchid strains FC-502, 507, and 509, were pathogenic to Phalaenopsis and Cattleya, but not Dendrobium. Water-soaked lesions were visible after 7-10 days and the tissue became black after 14-21 days. Strain FC-503 was weakly virulent on Phalaenopsis and Cattleya. Control plants injected with water did not develop any symptoms.

\section{DNA preparation and DNA/DNA reassociation assays}

Results of DNA/DNA reassociation assays revealed four (A, B, C, and D) distinct genotypes among the A. avenae strains (Table 1 ), based upon $70 \%$ or greater similarity $[37,48,53]$. Taxon A included six A. avenae subsp. avenae strains from corn that had a mean reciprocal similarity of $81 \%$; taxon $\mathrm{B}$ included six $A$. avenae subsp. avenae strains from rice that had a mean reciprocal similarity of $97 \%$; taxon C contained 11 $A$. avenae subsp. citrulli strains from cucurbits that had a mean reciprocal similarity of $88 \%$; and taxon D contained four A. avenae subsp. cattleyae strains from orchids that had a similarity of $98 \%$. The mean reciprocal relatedness between taxa $\mathrm{A}, \mathrm{B}, \mathrm{C}$, and $\mathrm{D}$ was less than $70 \%$ (Table 1). The two tea strains were $100 \%$ similar to each other but shared less than $70 \%$ relatedness to any of the four taxa above. The single strains from millet and finger millet and the six strains of $A$. avenae were moderately related but all showed less 
Table 1. Percentage DNA relatedness between strains of phytopathogenic Acidovorax avenae subsp. avenae (Aaa) from corn, finger millet, millet, tea, vasey grass and rice. A. avenae subsp. citrulli (Aac) from curcurbits, A. avenae subsp. cattleyae (Aaca) from orchid, A. konjaci (Ak) from konjac, Acidovorax anthurii (Aan) from anthurium, Acidovorax valerianellae (Av) from lamb's lettuce and between $A$. facilis (Af), A. temperans (At), A. delafieldii (Adf), and A. defluvii (Adv), as determined by the $\mathrm{S} 1 \mathrm{nuclease}$ method using single-stranded target DNAs and ${ }^{33} \mathrm{P}$-labeled single-stranded probe DNAs at $T_{\mathrm{m}}-15^{\circ} \mathrm{C}$

${ }^{33}$ P-labelled probe DNAs, percentage aanealing

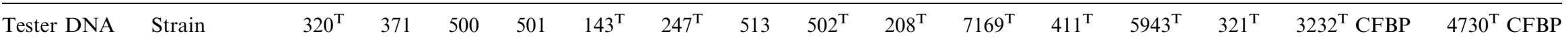

Taxon A, mean internal relatedness: $181 \%^{\mathrm{a}}$

$\begin{array}{llllll}\text { Aaa } & \text { FC } 320^{\mathrm{T}} & \mathbf{1 0 0}^{\mathrm{b}} & 85^{\mathrm{c}} & 63 & 65 \\ & \text { FC } 135 & 91 & 79 & 63 & 67 \\ & \text { FC } 371 & 90 & \mathbf{1 0 0} & 65 & - \\ \text { FC } 965 & 87 & 75 & 58 & - \\ \text { FC } 966 & { }^{\mathrm{d}} & 70 & - & 66 \\ & \text { FC } 369 & - & 72 & 68 & 61\end{array}$

Taxon B, mean internal relatedness; $97 \%$

$\begin{array}{lll}\text { FC } 143^{\mathrm{T}} & 43 & 52 \\ \text { FC } 499 & 49 & 46 \\ \text { FC } 192 & 62 & 49 \\ \text { FC 00 } & 62 & 42 \\ \text { FC } 504 & 44 & 48 \\ \text { FC } 155 & 53 & 46\end{array}$

Taxon $\mathrm{C}$, mean internal relatedness; $88 \%$

$\begin{array}{llllll}\text { FC 4 }^{\mathrm{T}} & 30 & 35 & 25 & 38 & 40 \\ \text { FC } 183 & - & 28 & 35 & 35 & 47 \\ \text { FC 374 } & - & 30 & 27 & 35 & 4 \\ \text { FC 376 } & 30 & - & - & - & - \\ \text { FC 379 } & - & - & - & - & - \\ \text { FC 440 } & - & 30 & 26 & 38 & 39 \\ \text { FC 464 } & - & - & - & - & - \\ \text { FC 513 } & 30 & 32 & 31 & 38 & 4 \\ \text { FC 526 } & - & 30 & - & 37 & 45 \\ \text { FC 528 } & 26 & 36 & 31 & 36 & 42 \\ \text { FC 356 } & - & 29 & 25 & 39 & 37\end{array}$

Taxon D, mean internal relatedness; $98 \%$

Aaca $\quad$ FC $502^{\mathrm{T}} \quad 34$

\begin{tabular}{lllllll} 
Aaca & FC $502^{\mathrm{T}}$ & 34 & 37 & 38 & 44 & 40 \\
& FC 503 & - & 42 & 27 & 44 & 47 \\
& FC 507 & 35 & 32 & 39 & 40 & 47 \\
\multirow{4}{*}{ Aaa } & FC 509 & 30 & 37 & - & 42 & 46 \\
& FC 185 & 60 & 64 & 60 & 67 & 46 \\
& FC 500 & 55 & 57 & $\mathbf{1 0 0}$ & 66 & 53 \\
& FC 501 & 63 & 66 & 58 & $\mathbf{1 0 0}$ & 55 \\
& FC 506 & - & 59 & 54 & 100 & 55 \\
& FC 180 & 54 & 59 & 53 & 64 & 4
\end{tabular}

Aaa

$\begin{array}{lllllll}52 & 48 & 68 & \mathbf{1 0 0} & 45 & 43 & - \\ 46 & 50 & 57 & 99 & 43 & 40 & - \\ 49 & 56 & 63 & 90 & - & - & 22 \\ 42 & 43 & 58 & 98 & - & - & 23 \\ 48 & 44 & 56 & 98 & - & - & 3 \\ 46 & 39 & 61 & 100 & - & - & -\end{array}$

$\mathbf{1 0 0}$
92
100
94
97
96
91
82
85
80
80

$\begin{array}{ll}79 & 21 \\ 92 & - \\ 83 & 30 \\ 93 & - \\ 92 & - \\ 83 & 25 \\ 84 & - \\ \mathbf{1 0 0} & - \\ - & - \\ - & - \\ - & -\end{array}$

6
5
9
-
-
6
-
6
3
0
8

$\begin{array}{lll}18^{\mathrm{e}} & \\ - & - \\ - & - \\ - & - \\ - & -\end{array}$

$\begin{array}{lll}17^{\mathrm{e}} & 1 & 8 \\ - & - & - \\ - & 7 & 4 \\ - & 8 & - \\ - & - & - \\ - & - & -\end{array}$




\begin{tabular}{|c|c|c|c|c|c|c|c|c|c|c|c|c|c|c|c|c|}
\hline Af & $\mathrm{FC08}$ & 3 & 3 & 8 & 5 & 3 & 3 & 3 & 0 & 100 & $45^{\mathrm{e}}$ & $17^{\mathrm{e}}$ & $56^{\mathrm{e}}$ & 3 & 5 & 10 \\
\hline At & LMG $7169^{\mathrm{T}}$ & $15^{\mathrm{e}}$ & - & - & - & - & - & - & - & - & $100^{\mathrm{e}}$ & $22^{\mathrm{e}}$ & $23^{\mathrm{e}}$ & $10 \mathrm{e}$ & - & - \\
\hline Adv & $\mathrm{BSB} 411^{\mathrm{T}}$ & $14^{\mathrm{e}}$ & - & - & - & - & - & - & - & - & $33^{\mathrm{e}}$ & $100^{\mathrm{e}}$ & $25^{\mathrm{e}}$ & $16 \mathrm{e}$ & - & - \\
\hline Adf & LMG $5943^{\mathrm{T}}$ & $25^{\mathrm{e}}$ & - & - & - & - & - & - & - & - & $28^{\mathrm{e}}$ & $38^{\mathrm{e}}$ & $100^{\mathrm{e}}$ & $25 \mathrm{e}$ & - & - \\
\hline \multirow[t]{2}{*}{$\mathrm{Ak}$} & $\mathrm{FC} 321^{\mathrm{T}}$ & 9 & 11 & 0 & 13 & 12 & 15 & 6 & 3 & 7 & $15^{\mathrm{e}}$ & $20^{\mathrm{e}}$ & $15^{\mathrm{e}}$ & 100 & 4 & 1 \\
\hline & FC 505 & - & 8 & 2 & 13 & 10 & - & - & 6 & 6 & - & - & - & 100 & 11 & 10 \\
\hline \multirow[t]{3}{*}{ Aan } & CFBP 4344 & - & - & - & - & - & - & - & - & - & - & - & - & - & 100 & - \\
\hline & CFBP 3242 & - & - & - & - & - & - & - & - & - & - & - & - & - & 100 & - \\
\hline & CFBP $3232^{\mathrm{T}}$ & 8 & 7 & - & 7 & 9 & 5 & 4 & 1 & 2 & - & - & - & 10 & 100 & 8 \\
\hline \multirow[t]{2}{*}{$\mathrm{Av}$} & CFBP $4730^{\mathrm{T}}$ & 5 & 2 & - & 2 & 3 & 5 & 1 & 1 & 2 & - & - & - & 12 & 20 & 100 \\
\hline & CFBP 6487 & - & - & - & - & - & - & - & - & - & - & - & - & - & - & 100 \\
\hline
\end{tabular}

Taxon A:B relatedness, $51 \%$ f

Taxon B:C relatedness, $42 \%$.

Taxon A:C relatedness, $32 \%$.

Taxon A:D relatedness, $33 \%$

Taxon B:D relatedness, $35 \%$.

Taxon C:D relatedness, $31 \%$

${ }^{a}$ Mean internal \% DNA relatedness: mean calculated from heterologous pairwise tests (non-bolded figures) within the taxon (boxed figures) but excluding $100 \%$ homologous values.

${ }^{b}$ Controls: homologous reassociations (bolded figures) between the probe and tester single-stranded DNAs from the same strain were set to $100 \%$ DNA relatedness; heterologous reassociations

between the probe and salmon sperm single-stranded DNAs (not shown) were set to $0 \%$ DNA relatedness.

${ }^{\mathrm{c}}$ Heterologous pairwise reassociations (non-bolded figures) between ${ }^{33} \mathrm{P}$-labeled and tester single-stranded DNAs; average of at least two determinations presented

${ }^{\mathrm{d}}$ Pair-wise test not performed.

${ }^{\mathrm{e}}$ Data from Schulze et al., [45] using $T_{\mathrm{m}}-25^{\circ} \mathrm{C}$.

${ }^{\mathrm{f}}$ Mean reciprocal \% DNA relatedness calculated from pair-wise, heterologous tests between two taxa. 
than $70 \%$ relatedness to the other taxa. The strains from konjac and strains of $A$. anthurii and $A$. valerianellae had $19 \%$ or less similarity with strains of $A$. avenae. All other strains of Acidovorax shared a similarity of $25 \%$ or less with $A$. avenae (Table 1).

\section{AFLP analysis}

Similarities between the non-phytopathogenic strains (A. facilis, C. testosteroni, and P. pseudoalcaligenes) and the phytopathogenic strains (except $A$. konjaci) were less than $18 \%$ (Fig. 1). These AFLP data correlated highly with DNA/DNA homology groupings: strains that fell into the same DNA/DNA homology group also clustered closely with AFLP. Phylogenetic analysis of AFLP patterns revealed four major host-based clusters among the phytopathogenic strains: corn (with minimal internal linkage of $68 \%)$, rice $(44 \%)$, cucurbits $(58 \%)$, and orchids $(68 \%)$. Strains from konjac clustered into a distinct group separately from the other phytopathogens at a similarity coefficient of less than $20 \%$.

\section{Phenotypic characteristics}

Results with $A$. avenae (Table S-3) were in good agreement with the previous data of Willems et al. [55] and Schaad et al. [41]. Strains of $A$. avenae were easily distinguished from each other and from all other described species $A$. konjaci, A. delafieldii, A. temperans,
A. defluvii, A. anthurii, A. valerianellae, A. caeni, and A. facilis (Table S-3).

\section{Fatty acids}

None of the phytopathogenic strains, except A. valerianellae, A. anthurii and A. konjaci, contained the 3-hydroxyoctanoic acid (8:0 3-OH). In contrast, fatty acid 8:0 3-OH was present in A. facilis (Table S-4) and the other non-phytopathogenic species [18].

\section{S rDNA and 16S-23S rDNA internal transcribed spacer (ITS) region sequencing}

The phytopathogenic A. avenae strains from rice, tea, corn, watermelon, and orchid, were highly related by $16 \mathrm{~S}$ rDNA sequencing forming a tight cluster with three lineages (Fig. 2). The percentage similarity values among the $A$. avenae strains ranged from $99.7 \%$ to $100 \%(1-5$ nucleotides different). The strains from corn and rice differed by two nucleotides (nts). A. konjaci, A. anthurii and A. valerianellae were $98.1 \%$ (28 nts), $98.3 \%$ (25 nts), and $98.0 \%$ (30 nts) similar to $A$. avenae $\mathrm{FC}-320^{\mathrm{T}}$, respectively. All were clearly distinguishable from the non-phytopathogenic A. temperans, A. facilis, $A$. defluvii, A. caeni, and A. delafieldii (Fig. 2) with similarities of $96.7-98.4 \%$ (24-49 nts different). The newly described plant pathogenic $A$. anthurii formed a separate

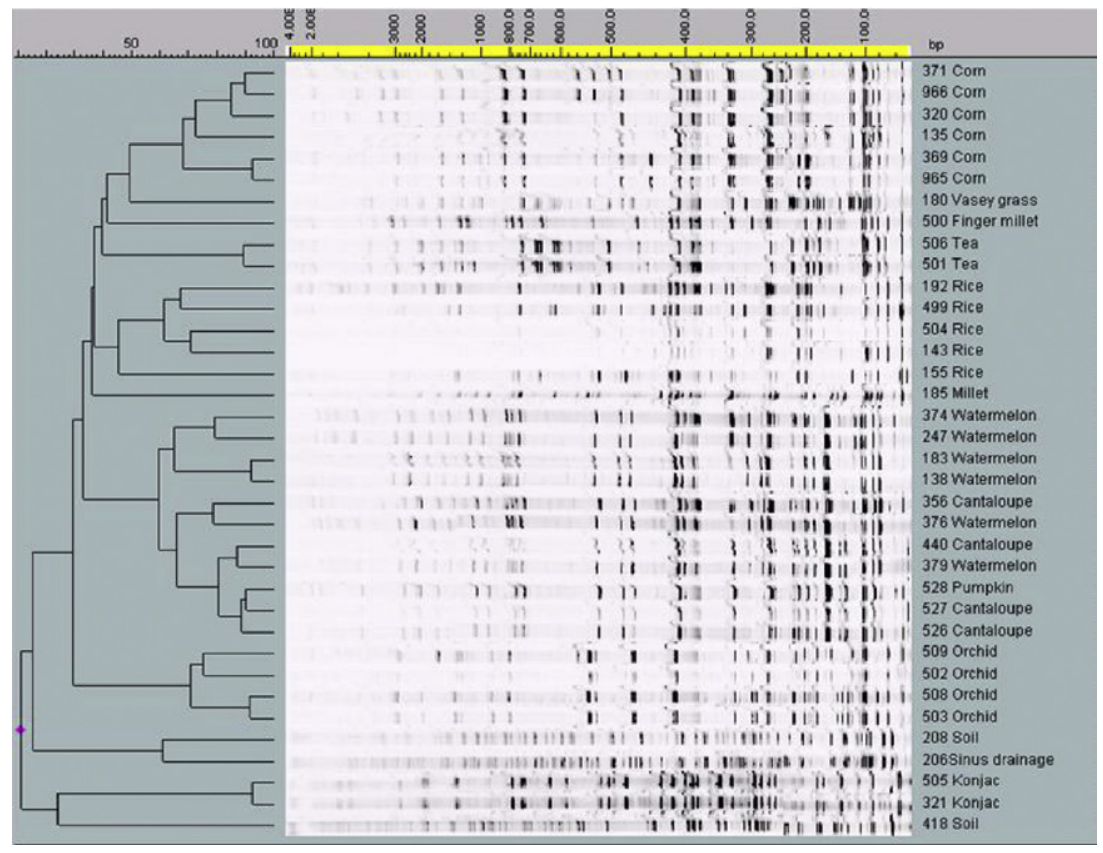

Fig. 1. AFLP patterns of genomic DNA for phytopathogenic Acidovorax avenae strains from corn, rice, finger millet, vasey grass, tea, orchid, watermelon, cantaloupe, and pumpkin, A. konjaci from konjac; and non-phytopathogenic strains of $A$. facilis (20 8), Pseudomonas pseudoalcaligenes (206), and Comamonas testosteroni (418). The dendrogram was constructed by using the unweighted pair group method with averages (UPGMA). Strain codes are the same as presented in Table S-1. 


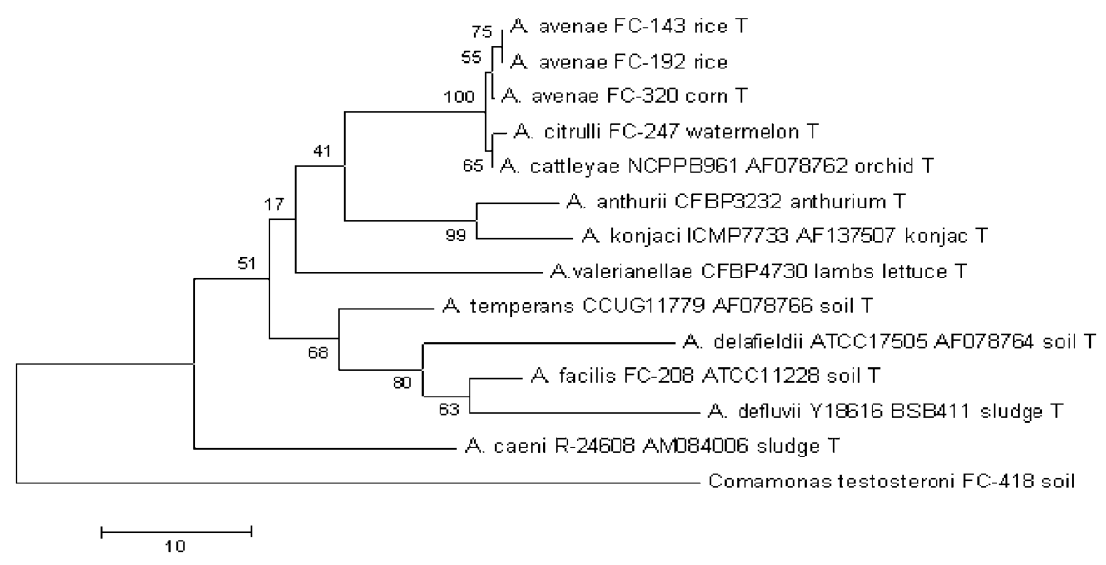

Fig. 2. 16S rDNA neighbor-joining consensus tree of strains of Acidovorax avenae subsp. avenae (A. avenae), A. avenae subsp. cattleyae (A. cattleyae), A. avenae subsp. citrulli (A. citrulli), A. konjaci, A. anthurii, A. valerianellae, A. temperans, A. delafieldii, A. defluvii, A. caeni, Comamonas testosteroni, and A. facilis. Distance between strains was measured as a number of nucleotide differences. Data for strains designated AF and Y were obtained from GenBank. Strains FC-143 and 192 are proposed to be named A. oryzae.

group more closely related to $A$. konjaci, whereas A. valerianellae was more distant (Fig. 2).

The ITS similarities among strains of A. avenae from corn, rice, cucurbits, and orchids ranged from 97.3 (orchid vs. cucurbit strains) to $99.0 \%$ (corn vs. rice strains) (Table 2) (16 and $6 \mathrm{nts}$ ), respectively. Tea strains, FC-501 and FC-506 and finger millet strain FC500 shared $99.5 \%$ (3 nts) and $99.7 \%$ similarity ( $2 \mathrm{nts}$ ), respectively, with the type strain of $A$. avenae subsp. avenae. The other three plant pathogenic species, A. konjaci, $A$. anthurii and $A$. valerianellae shared similarities of only 81.8 (109 nts) $-87.8 \%$ (73 nts) with the $A$. avenae strains from corn, rice, cucurbits, and orchids.

The following 16S rDNA and ITS sequences were deposited in GenBank: 16S rDNA sequences included DQ360414 (FC-143, ATCC19882, rice), DQ360415 (FC-501, Supp86, tea) and DQ360416 (FC-500, Supp150, finger millet). ITS sequences included EU368726 (FC-320, corn), DQ360417 (FC-502, Supp 364, orchid), DQ360418 (FC-247, ATCC 29625, watermelon), DQ360420 (FC-143, rice), DQ360422 (FC-500, finger millet), DQ360423 (FC-501, tea), DQ360425 (FC-208; ATCC11228, soil).

\section{Discussion}

The results support the elevation of two subspecies of Acidovorax to species rank, and the naming of a new species. In this regard, the results agree with some of the groupings previously reported by Willems et al. [55], who observed two main DNA/DNA similarity groups at the species level within the phytopathogenic strains. Group one, related at a $54-100 \%$ similarity, contained strains of $[P$.$] avenae, [P$.$] rubrilineans, "[P.] setariae",$ $[P$.] cattleyae, and $[P$.$] pseudoalcaligenes subsp. citrulli.$ Within this group, three subgroups were delineated; subgroup one contained strains of $[P$.] avenae, $[P$.] rubrilineans, and " $[P$. $]$ setariae" which were $75-100 \%$ similar; subgroup two contained strains of $[P$.] cattleyae which were $95 \%$ similar; and subgroup three contained strains of $[P$.$] pseudoalcaligenes subsp. citrulli, which$ were $93-100 \%$ similar. Group two contained $[P$.] konjaci. Willems et al. [55] proposed combining the corn, sugarcane, and rice strains of group one into Acidovorax as a single subspecies, A. avenae subsp. avenae, based on a DNA/DNA similarity range of 74-100\%. However, our DNA/DNA reassociation assays showed the corn and rice strains were not the same species, since they shared a mean reciprocal similarity of only $51 \%$ (range $43-68 \%$ ). These DNA data agree with previous results showing differences between corn and rice strains in cell protein profiles [25,51] serology [10,25], and carbohydrate utilization [41]. Therefore, we agree that the corn and rice strains should be considered as separate species [50]. Although not cited by Willems et al. [55], rice strains had been shown earlier to differ phenotypically from $[P$. $]$ avenae [16]. Goto and Ohata suggested the rice organism be called " $P$. setariae until more conclusive evidence will be established" [17]. Discrepancies between the DNA/ DNA reassociation data of Willems et al. [55] and our findings are most likely due to differences in protocols used for DNA/DNA reassociation. The much less robust spectrophotometric method used by Willems et al. [55] is based on an initial renaturation rate technique [5], which does not allow reciprocal tests [6] and uses an equal amount of labeled and unlabeled DNA. Since no S1 nuclease is included, mismatched fragments and loops are not degraded and results often 
Table 2. Summary of characters useful for differentiating between species of Acidovorax, A. avenae (Aa), A. oryzae (Ao), A. citrulli (Ac), and A. cattleyae (Aca)

\begin{tabular}{|c|c|c|c|c|}
\hline \multirow[t]{2}{*}{ Character } & \multicolumn{4}{|l|}{ Species } \\
\hline & $\mathrm{Aa}(6)^{\mathrm{a}}$ & Ao (6) & Ac (11) & Aca (4) \\
\hline \multicolumn{5}{|c|}{ DNA/DNA relatedness to ${ }^{b}$} \\
\hline A. avenae & 81 & 53 & 39 & 27 \\
\hline A. oryzae & 46 & 97 & 43 & 25 \\
\hline A. citrulli & 47 & 43 & 88 & 25 \\
\hline A. cattleyae & 35 & 45 & 39 & 98 \\
\hline \multicolumn{5}{|l|}{ ITS similarity to ${ }^{c}$} \\
\hline A. avenae & 100 & 99.0 & 98.0 & 98.3 \\
\hline A. oryzae & 99.0 & 100 & 97.8 & 98.0 \\
\hline A. citrulli & 98.0 & 97.8 & 100 & 97.3 \\
\hline A. cattleyae & 98.3 & 98.0 & 97.3 & 100 \\
\hline \multicolumn{5}{|l|}{ Utilization of } \\
\hline D-arabitol & $-{ }^{\mathrm{d}}$ & - & $\mathrm{V}^{+}$ & + \\
\hline Sodium citrate & + & - & + & + \\
\hline Maltose & + & - & - & - \\
\hline D-fucose & $\mathrm{V}^{+}$ & + & $\left(\mathrm{V}^{+}\right)^{3}$ & $-{ }^{2}$ \\
\hline D-mannitol & + & + & - & + \\
\hline Ethanol & - & + & + & + \\
\hline Lipase production & + & + & - & + \\
\hline Gelatin liquefaction & $(+)$ & $(+)$ & $(+)$ & - \\
\hline Nitrate reduction & + & + & - & + \\
\hline $\begin{array}{l}\text { Litmus milk } \\
\text { Reaction to } \mathrm{PCR}^{\mathrm{e}}\end{array}$ & Alk & Alk & Alk (P) & Alk \\
\hline Aaaf5, Aaaf3/Aaar2 & - & + & - & - \\
\hline Aacf2/Aacr2 & - & - & + & - \\
\hline Hosts & Corn & Rice & Cucurbits & Orchid \\
\hline
\end{tabular}

${ }^{\mathrm{a}}$ Number in parenthesis represents the number of strains tested.

${ }^{\mathrm{b}}$ DNA/DNA reassociations were carried out at $T_{\mathrm{m}}-15$; figures are a mean percentage.

${ }^{\mathrm{c}}$ ITS, 16S-23S internally transcribed spacer region; figures are a percentage.

$\mathrm{d}+, 80 \%$ or more of all strains positive; $(+)$, delayed positive; ,$- 80 \%$ or more of all strains negative; $\mathrm{V}^{+}, 50-79 \%$ positive; $\mathrm{V}^{-}$, $19-49 \%$ negative.

${ }^{\mathrm{e}}$ Based on the polymerase chain reaction (PCR) using the same strains for DNA/DNA reassociations.

lead to artificially higher DNA similarity values [21]. The S1 nuclease method used in our study has been shown to lower similarity values by as much as $15-20 \%$ [22,21] when compared to the spectrophotometric method. Also, Willems et al. [54] used a less stringent renaturation temperature of $82^{\circ} \mathrm{C}$, whereas we used $84+1{ }^{\circ} \mathrm{C}\left(71+1{ }^{\circ} \mathrm{C}\right.$ in the presence of $22.7 \%$ formamide). This discrepancy in reassociation temperature occurred because of the different $\mathrm{mol} \% \mathrm{G}+\mathrm{C}$ content used to determine the renaturation temperature. Willems et al. [55] used a $\mathrm{mol} \% \mathrm{G}+\mathrm{C}$ content of $69.8 \%$ in determining their reassociation temperature for $A$. avenae, rather than the previously reported $72.2 \%$ [40]. Use of such a reduced temperature would result in a lower stringency and therefore a higher percentage similarity [5]. Schulze et al. [45] reported $70 \%$ and $77 \%$ similarity between $A$. avenae subsp. avenae and cattleyae and between $A$. avenae subsp. avenae and citrulli, respectively. In contrast, our results showed a mean similarity of $33 \%$ and $32 \%$, respectively. They used a single strain and reported observing differences of up to $21 \%$, and suggested the variation was due to differences in DNA quality. Also, they used a stringency of $65^{\circ} \mathrm{C}$ whereas we used $71^{\circ} \mathrm{C}$.

Our AFLP results agreed with the DNA/DNA similarity results and clearly showed each of the four taxa including the corn and rice strains were easily differentiated from each other and from the nonphytopathogens, as well as A. konjaci. These results support the use of AFLP assays for identification of some phytopathogenic bacteria at the species level [30].

The 16S and ITS sequencing results clearly differentiated between $A$. avenae strains, as well as between $A$. avenae and all other species of Acidovorax. Our results agree with previous results showing most phytopathogenic A. avenae subsp. avenae, subsp. citrulli, and subsp. cattleyae strains could be differentiated easily from each other by phenotypic traits $[4,15,20,40,41,55]$, cellular protein profiles [25], and serology [24]. A. valerianellae was the only pathogen that failed to grow at $41^{\circ} \mathrm{C}[12$, this study]. $A$. anthurii and $A$. valerianellae were easily separated from $A$. avenae. Unlike $A$. avenae, $A$. anthurii did not utilize L-tryptophan [11] and $A$. valerianellae failed to utilize D-sorbitol, adipate, ethanolamine, reduce nitrate, liquefy gelatin, or produce lipase [this study, 12]. Neither $A$. anthurii nor $A$. valerianellae utilized D-xylose, or produced alkaline from litmus milk, whereas $A$. avenae did (Table S-3). Both contained the fatty acid 3-hydroxyoctanoic acid (8:0 3-OH). All $A$. avenae species utilized D-glucose and adipate, whereas A. caeni did not. A. avenae did not contain the fatty acid 8:0 3-OH, whereas A. caeni did [18]. Strains of $A$. delafieldii, $A$. temperans, and $A$. defluvii were very different from $A$. avenae (Table S-3). A. defluvii failed to grow at $37^{\circ} \mathrm{C}$ [45], did not utilize D-glucose, D-sorbitol or ethanolamine, and nor did it liquefy gelatin (Table S-3), but it contained the fatty acid 8:0 3-OH $[18,45]$. Our results do not agree that all strains of recognized Acidovorax species contain the fatty acid 8:03-OH [18] unless one places the plant species into another genera.

These genetic (16S, ITS sequencing, DNA/DNA reassociation assays, AFLP analysis) and phenotypic data, including fatty acid profiles, support an emendation of the species $A$. avenae. Since $A$. avenae Group A corn strains and Group B rice strains have less than $70 \%$ DNA/DNA similarity, differ serologically [24], have distinct protein patterns [25], and can be differentiated phenotypically, we propose a new species, A. oryzae, for Group B strains from rice. We propose Group C strains from cucurbits and Group D strains from orchids be elevated to species rank as $A$. citrulli and A. cattleyae, 
respectively. Although strains from tea, vasey grass, finger millet, and millet shared a moderate DNA/DNA similarity of $54 \%$ to $68 \%$ with $A$. avenae, suggesting separate species, we would suggest that these strains be classified as Acidovorax spp. until additional strains are tested.

\section{Summary of characters}

Table 2 summarizes some of the most important characters for distinguishing between Acidovorax avenae, A. oryzae, A. citrulli, and A. cattleyae.

\section{Protologues}

Abbreviations for culture collections and depositories of type strains are:

ATCC $=$ American Type Culture Collection, Manassas, VA, USA;

$\mathrm{CFBP}=$ Collection Francaise de Bacteries Phytopathogenes, Angers, France;

ICMP = International Collection of Microorganisms from Plants, Auckland, New Zealand;

ICPB = International Collection of Phytopathogenic

Bacteria, USDA, Ft. Detrick, MD;

$\mathrm{LMG}=$ Laboratorium Microbiologie Gent, Belgium;

$\mathrm{NCPPB}=$ National Collection of Plant Pathogenic

Bacteria, England;

$\mathrm{IBSBF}=$ Instituto Biologico, Seçao de Bacteriologia

Fitopatologica, Campinas, SP, Brazil.

\section{Acidovorax avenae (Manns 1909) Willems et al., 1992}

Acidovorax avenae (a.ve'na. e. N.L. gen. n. avenae, of Avena, a genus of oat plants).

Basonym: Pseudomonas avenae Manns 1909 (Approved Lists 1980).

Other homotypic synonyms: Pseudomonas avenae subsp. avenae Manns 1909, Acidovorax avenae subsp. avenae (Manns 1909) Willems et al., 1992. Another heterotypic synonym: Pseudomons rubrilineans (Lee et al., 1925) Strap 1928.

The species is pathogenic to corn and oats, whereas pathogenicity to wheat is variable.

Acidovorax avenae can be distinguished from A. oryzae, A. citrulli, and A. cattleyae by DNA/DNA reassociation assays (Table 1), PCR, AFLP analysis (Fig. 1), and phenotypic traits (Tables 2 and S-3) [this paper, 15,20,40,54,55]. Nitrate is reduced and an alkaline reaction is produced in litmus milk. Arginine is not dihydrolyzed. Gelatin is weakly liquefied. A. avenae utilizes D-glucose, D-xylose, D-mannitol, adipate, D-frucose, D-mannose, citraconate, D-sorbitol, maltose [this paper], $\beta$-alanine [41], L-leucine [38], L-arabinose, D-galactose, isobutyrate, isovalerate, pimelate, L-threonine, L-histidine, L-tryptophan, 2-ketoglutarate, and malonate [55]. D-arabitol and ethanol are not utilized (Table S-3). Starch hydrolysis is negative and ammonia is not produced. [40]. Acidovorax avenae utilizes sodium citrate and maltose, whereas $A$. oryzae does not (Tables 2 and S-3).

Type strain: $\quad$ FC $-320^{\mathrm{T}}=$ ICPB $30071(\mathrm{PA} 117)^{\mathrm{T}}=$ ATCC $19860^{\mathrm{T}}=$ NCPPB $1011^{\mathrm{T}}=\mathrm{LMG} \quad 2117^{\mathrm{T}}=$ $\operatorname{ICMP} 3183^{\mathrm{T}}=$ CFBP $2425^{\mathrm{T}}=\operatorname{IBSBF} 193^{\mathrm{T}}$.

\section{Acidovorax oryzae sp. nov.}

Acidovorax oryzae [o.ry'za. e. L. gen. n. oryzae, of rice, of Oryza (a genus of rice plants)].

The species infects rice. Acidovorax oryzae can be distinguished from $A$. avenae, A. citrulli, and A. cattleyae by DNA/DNA reassociation assays (Table 1), AFLP analysis (Fig. 1), and several phenotypic traits (Tables 2 and S-3) $[14,16]$. Gelatin is weakly liquefied. D-mannose and D-fructose are utilized by A. oryzae, whereas utilization by $A$. avenae and $A$. citrulli is variable. Acidovorax oryzae utilizes ethanol, whereas $A$. avenae does not. A. oryzae does not utilize sodium citrate or maltose, whereas $A$. avenae does. Acidovorax oryzae utilizes D-mannitol, reduces nitrate and hydrolyzes lipid, whereas $A$. citrulli does not. A. oryzae does not utilize D-arabitol, whereas $A$. cattleyae does. Acidovorax oryzae utilizes D-fucose whereas $A$. avenae and $A$. citrulli are variable, and $A$. cattleyae is negative. Arginine is not dihydrolyzed. All strains react with PCR primers Aaaf5 or Aaaf3/Aaar2, whereas A. avenae, A. citrulli, and A. cattleyae do not (Table 2) [47].

Type strain: $\mathrm{FC}-143^{\mathrm{T}}=\mathrm{ICPB} 30003(\mathrm{PS} 177)^{\mathrm{T}}=$ ATCC $19882^{\mathrm{T}}=$ NCPPB $1392^{\mathrm{T}}=\operatorname{ICMP} 3960^{\mathrm{T}}$.

\section{Acidovorax citrulli (Schaad et al. 1978) comb. nov.}

Acidovorax citrulli (ci.trul'li. N.L. gen. n. citrulli, of Citrullus, a genus of melon plants).

Basonym: Pseudomonas pseudoalcaligenes subsp. citrulli Schaad et al. 1978 (Approved Lists 1980).

Other homotypic synonyms: Pseudomonas avenae subsp. citrulli (Schaad et al. 1978) Hu et al. 1991, Acidovorax avenae subsp. citrulli (Schaad et al. 1978) Willems et al. 1992.

The bacterium infects many plants in the Cucurbitaceae. Acidovorax citrulli can be distinguished from A. avenae, $A$. oryzae, and $A$. cattleyae by DNA/DNA reassociation assays (Table 1), AFLP analysis (Fig. 1), and several phenotypic traits (Tables 2 and S-3) $[19,41,55]$. Gelatin is weakly liquefied and delayed (Tables 2 and S-3) [41]. The bacterium does not reduce nitrate, or produce lipase, whereas $A$. avenae and 
A. oryzae do. Alkali is produced in litmus milk and a precipitate forms (Tables 2 and S-3); no precipitate is produced by $A$. avenae, A. oryzae, or A. cattleyae. Acidovorax citrulli does not utilize D-mannitol whereas A. oryzae, A. avenae and A. cattleyae do (Tables 2 and $\mathrm{S}-3)$. The organism utilizes sodium citrate, ethanol, ethanolamine, citraconate, adipate, and D-sorbitol (Tables 2 and S-3), $\beta$-alanine, L-arabinose, D-galactose, D-ribose, DL-tartrate [15]; 2-ketoglutrate [55] but not L-histidine, and L-threonine [55]. Arginine is not dihydrolyzed. Acidovorax citrulli reacts with PCR primers Aacf2/Aacr2, whereas A. avenae, A. oryzae, and A. cattleyae do not (Table 2) [46].

Type strain: $\quad$ FC $-247^{\mathrm{T}}=\mathrm{ICPB} \quad 30064^{\mathrm{T}}=\mathrm{ATCC}$ $29625^{\mathrm{T}}=\operatorname{ICMP} 7500^{\mathrm{T}}=\operatorname{IBSBF} 1851^{\mathrm{T}}$.

\section{Acidovorax cattleyae (Pavarino 1911) comb. nov.}

Acidovorax cattleyae (cat.tle'ya. e. N.L. gen. n. cattleyae, of Cattleya, a genus of orchid plants).

Basonym: Pseudomonas cattleyae (Pavarino 1911) Savulescu 1947 (Approved Lists 1980).

Other homotypic synonym: Acidovorax avenae subsp. cattleyae (Pavarino 1911) Willems et al. 1992.

The organism naturally infects Cattleya, Dendrobium, Phalaenopsis, and their hybrids. Acidovorax cattleyae can be distinguished from $A$. avenae, A. citrulli, and $A$. oryzae by DNA/DNA reassociation assays (Table 1 ), AFLP analysis (Fig. 1), and several phenotypic traits (Tables 2 and S-3) [1,20,55]. Nitrate is reduced. A. cattleyae utilizes D-glucose, D-xylose, D-mannitol, D-sorbitol, sodium citrate, adipate, D-mannose, citraconate, D-arabitol, ethanolamine, ethanol (Tables 2 and S-3), L-arabinose, dulcitol, galactose, glycerol, lactose, sucrose [1] and does not utilize D-fucose. The bacterium utilizes sodium citrate, whereas $A$. oryzae does not, and D-mannitol, whereas $A$. citrulli does not (Table 2). A. cattleyae utilizes D-arabitol, whereas $A$. avenae and A. oryzae do not. A. cattleyae does not utilize maltose, whereas $A$. avenae does. It does not liquefy gelatin, whereas $A$. avenae, A. oryzae, and $A$. citrulli do.

Type strain: $\quad \mathrm{FC}-507^{\mathrm{T}}=\mathrm{ICPB} 30134 \quad(\mathrm{PC} 21)^{\mathrm{T}}=$ ATCC $33619^{\mathrm{T}}=$ NCPPB $961^{\mathrm{T}}=$ LMG $2364^{\mathrm{T}}=$ ICMP $2826^{\mathrm{T}}=$ CFBP $2423^{\mathrm{T}}=$ IBSBF $209^{\mathrm{T}}$.

All strains are available in the International Collection of Phytobacteriology (ICPB) maintained at the USDA ARS, FDWSRU, Fort Detrick, MD (N.W. Schaad and A. Sechler, Curators).

\section{Acknowledgements}

We thank Vern Damsteegt, Bill Bruckart, and Nina Shishkoff, for reviewing the manuscript and A. Mavridis, Y. Takikawa, and M. LeSaux, for supplying several cultures. We thank Y. Takikawa for reviewing the manuscript for our nomenclatural changes. We especially thank Jean Euzeby for editing our protologues.

The use of trade, firm, or corporation names in this publication is for the information and convenience of the reader. Such use does not constitute an official endorsement or approval by the United States Department of Agriculture or the Agricultural Research Service of any product or service to the exclusion of others that may be suitable.

\section{Appendix A. Supporting information}

Supplementary data associated with this article can be found in the online version at doi:10.1016/j.syapm. 2008.09.003.

\section{References}

[1] P.A. Ark, H.E. Thomas, Bacterial leaf spot and bud rot of orchids caused by Phytomonas cattleyae, Phytopathology 36 (1946) 695-698.

[2] J.F. Bradbury, Guide to Plant pathogenic Bacteria, CAB Int. Mycolog. Inst. Kew, England, 1986.

[3] J. Brosius, M.L. Palmer, P.J. Kennedy, H.F. Noller, Complete nucleotide sequence of a $16 \mathrm{~S}$ ribosomal RNA gene from Escherichia coli, Proc. Natl. Acad. Sci. USA 75 (1978) 4801-4805.

[4] L.E. Claflin, B.A. Ramundo, J.E. Leach, I.D. Erinle, Pseudomonas avenae, causal agent of bacterial leaf stripe of pearl millet, Pl. Dis. 73 (1989) 1010-1014.

[5] J. De Ley, Modern molecular methods in bacterial taxonomy: evaluation, application, prospects, in: Station Pathologie Vegetable Phytobacteriologie (Ed.), Proceedings of the 4th International Conference of Plant Pathogenic Bacteria, vol. 1, Gibert-Clarey, Tours, France, 1978, pp. 347-357.

[6] J. De Ley, J.H. Cattoirand, A. Reynaerts, The quantitative measurement of DNA hybridization from renaturation rates, Eur. J. Biochem. 12 (1970) 133-142.

[7] P.K. De Vos, M. Goor, M. Gillis, J. De Ley, Ribosomal ribonucleic acid cistron similarities of phytopathogenic Pseudomonas species, Int. J. Syst. Bacteriol. 35 (1985) 169-184.

[8] Difco Manual of Dehydrated Culture Media and Reagents for Microbiological and Clinical Laboratory Procedures. Difco Laboratories, Detroit, MI, 1982, p. 350 .

[9] C.A. Elliott, Bacterial stripe disease of proso millet, J. Agric. Res. 26 (1923) 151-160.

[10] C. Fang-Sik, Y. Nakajima, N. Tanaka, M. Iwano, T. Yoshida, S. Takayama, I. Kadota, A. Isogai, Flagellin from an incompatible strain of Pseudomonas avenae induces a resistance response in cultured rice cells, J. Biol. Chem. 275 (2000) 32347-32356. 
[11] L. Gardan, C. Dango, P. Prior, M. Gillis, G.S. Saddler, Acidovorax anthurii sp. nov., a new phytopathogenic bacterium which causes leaf-spot of Anthurium, Int. Syst. Evol. Microbiol. 50 (2000) 235-246.

[12] L. Gardan, D.E. Stead, C. Dango, M. Gillis, Acidovorax valerianellae sp. nov., a novel pathogen of lamb's lettuce [Valerianella locusta (L.) Laterr.], Int. Syst. Evol. Micrbiol. 53 (2003) 795-800.

[13] R.D. Gitatis, R.E. Stall, J.O. Strandberg, Dissemination and survival of Pseudomonas alboprecipitans ascertained by disease distribution, Phytopathology 68 (1978) 227-231.

[14] M. Goto, Nomenclature of the bacteria causing bacterial leaf streak and bacterial stripe of rice, Bull. Fac. Agric. Shizuoka Univ. 14 (1964) 3-10.

[15] M. Goto, Pseudomonas pseudoalcaligenes subsp. konjaci subsp. nov., the causal agent of bacterial leaf blight of konjac (Amorphalus konjac Koch.), Int. J. Syst. Bacteriol. 33 (1983) 539-545.

[16] K. Goto, K. Ohata, Bacterial stripe of rice, Natl. Taiwan Univ. Spec. Pub. 10 (1961) 49-59.

[17] A.C. Hayward, Studies on bacterial pathogens of sugar cane. II. Differentiation, taxonomy, and nomenclature of the bacteria causing red stripe and mottled stripe diseases, Mauritius Sugar Ind. Res. Inst. Occas. Pap. 13 (1962) 13-17.

[18] K. Heylen, L. Lebbe, P. De Vos, Acidovorax caeni sp. nov., a denitrifying species with genetically diverse isolates from activated sludge, Int. J. Syst. Evol. Bacteriol. 58 (2008) 73-77.

[19] D.C. Hildebrand, M.N. Schroth, D.C. Sands, Pseudomonas, in: N.W. Schaad (Ed.), Laboratory Guide for Identification of Plant Pathogenic Bacteria, 2nd ed., APS Press, St. Paul, MN, 1988, pp. 60-80.

[20] F.P. Hu, J.M. Young, C.M. Triggs, Numerical analysis and determinative tests for non-fluorescent plantpathogenic Pseudomonas spp. and genomic analysis and reclassification of species related to Pseudomonas avenae Manns 1909, Int. J. Syst. Bacteriol. 41 (1991) $516-525$.

[21] J.L. Johnson, DNA reassociation and RNA hybridization of bacterial nucleic acids, Methods Microbiol. 1 (1988) $33-74$.

[22] J.L. Johnson, Similarity analysis of DNAs, in: P. Gerhardt, R.G.E. Murray, W.A. Woods, N.R. Krieg (Eds.), Methods for General and Molecular Bacteriology, ASM, Washington, D.C., 1994, pp. 655-682.

[23] J.B. Jones, R.D. Gitaitis, N.W. Schaad, Acidovorax and Xylophilis, in: N.W. Schaad, J.B. Jones, W. Chun (Eds.), Laboratory Guide for Identification of Plant Pathogenic Bacteria, 3rd ed., APS Press, St. Paul, MN, 2001, pp. 121-138.

[24] I. Kadota, A. Ohuchi, K. Nishiyama, Serological properties and specificity of Pseudomonas avenae Manns 1909, the causal agent of bacterial brown stripe of rice, Ann. Phytopathol. Soc. Jpn. 57 (1991) 268-273.

[25] I. Kadota, I. Mizuno, K. Nishiyama, Detection of proteins specific to the strain of Pseudomonas avenae Manns 1909 pathogenic to rice, Ann. Phytopathol. Soc. Jpn. 62 (1996) 425-428.
[26] I. Kadota, A. Ohuchi, K. Nishiyama, Suppression of lesion enlargement of bacterial brown stripe of rice by living cells or cell extracts of Acidovorax spp, Ann. Phytopathol. Soc. Jpn. 64 (1998) 494-500.

[27] A.L. Kihupi, R.B. Mabagala, C.N. Mortensen, Occurrence of Acidovorax avenae subsp. avenae in rice seed in Tanzania, African Pl. Protect. 5 (1999) 55-58.

[28] D.B. Langston Jr., R.D. Walcott, R.D. Gitatis, F.H. Sanders Jr., First report of a fruit rot of pumpkin caused by Acidovorax avenae subsp. citrulli in Georgia, Plant Dis. 83 (1999) 199.

[29] X. Li, S.H. de Boer, Selection of polymerase chain reaction primers from an RNA intergenic spacer region for specific detection of Clavibacter michiganensis subsp. sepedonicus, Phytopathology 85 (1995) 837-842.

[30] F.J. Lowes, D.A. Cupples, Molecular Techniques, in: N.W. Schaad, J.B. Jones, W.L. Chun (Eds.), Laboratory Guide for Identification of Plant Pathogenic Bacteria, APS Press, St. Paul MN, 2001, pp. 321-333.

[31] T.F. Manns, The blade blight of oats - bacterial disease, Ohio Agric. Res. Stn. Res. Bull. 210 (1909) 91-167.

[32] N. Nishihara, A. Ezuka, Bacterial brown stripe of ragi caused by Pseudomonas alboprecipitans, Ann. Phytopathol. Soc. Jpn. 45 (1979) 25-31.

[33] N. Okabe, Bacterial diseases of plants occurring in Formosa IV. Bacterial brown stripe of Italian millet, J. Soc. Trop. Agric. Taiwan 6 (1934) 54-63.

[34] S.H. Ou, Rice Diseases, 2nd ed., Commonwealth Mycological Institute, Eastern Press Ltd., Kew, Surrey, England, 1986, p. 391.

[35] B.A. Ramundo, L.E. Claflin, Demonstration of synonymy between the plant pathogens Pseudomonas avenae and Pseudomonas rubrilineans, J. General Microbiol. 136 (1990) 2029-2033.

[36] H.R. Rosen, A bacterial disease of foxtail (Chaetochloa lutescens), Ann. Mo. Bot. Gard. 9 (1922) 333-388.

[37] R. Rossello-Mora, R. Amann, The species concept for prokaryotes, FEMS Microbiol. Rev. 25 (2001) 39-67.

[38] D.C. Sands, M.N. Schroth, D.C. Hildebrand, Pseudomonas, in: N.W. Schaad (Ed.), Laboratory Guide for Identification of Plant Pathogenic Bacteria, APS Press, St. Paul MN, 1980, pp. 36-44.

[39] M. Sasser, Identification of bacteria through fatty acid analysis, in: Z. Klement, K. Rudolph, D.C. Sands (Eds.), Methods in Phytobacteriology, Akademiai Kiado, Budapest, 1990, pp. 199-204.

[40] N.W. Schaad, C.I. Kado, D.R. Sumner, Synonymy of Pseudomonas avenae Manns 1905 and Pseudomonas alboprecipitans Rosen 1922, Int. J. Syst. Bacteriol. 25 (1975) 133-137.

[41] N.W. Schaad, G. Sowell, R.W. Goth, R.R. Colwell, R.E. Webb, Pseudomonas pseudoalcaligenes subsp. citrulli subsp. nov., Int. J. Syst. Bacteriol. 28 (1978) 117-125.

[42] N.W. Schaad, E. Postnikova, P. Randhawa, Emergence of Acidovorax avenae subsp. citrulli as a crop threatening disease of watermelon and melon, in: N.S. Iacobellis, et al. (Eds.), Pseudomonas syringae and related pathogens, Kluwer Academic Publishers, Dordrecht, 2003, pp. $573-581$. 
[43] N.W. Schaad, E. Postnikova, G. Lacy, M. Fatmi, C.J. Chang, Xylella fastidiosa subspecies: X. fastidiosa subsp. fastidiosa, subsp. nov., $X$. fastidiosa subsp. multiplex subsp. nov., and $X$. fastidiosa subsp. pauca subsp. nov., Syst. Appl. Microbiol. 27 (2004) 290-300.

[44] N.W. Schaad, E. Postnikova, G.H. Lacy, A. Sechler, I. Agarkova, P.E. Stromberg, V.K. Stromberg, A.K. Vidaver, Reclassification of Xanthomonas campestris pv. citri (ex Hasse 1915) Dye 1978 forms A, B, C, D, and $\mathrm{E}$ as $X$. smithii subsp. citri (ex Hasse) sp. nov. nom. rev. comb. nov.; $X$. fuscans subsp. aurantifolii (ex Gabriel 1987) sp. nov. nom. rev. comb. nov.; and $X$. alfalfae subsp. citrumelo sp. nov. nom. rev. comb. nov.; $X$. campestris pv. malvacearum (ex Smith 1901) Dye 1978 as $X$. smithii subsp. smithii sp. nov. comb. nov, nom. nov.; $X$. campestris pv. alfalfae (ex Riker and Jones, 1935) Dye 1978 as $X$. alfalfae subsp. alfalfae (ex Ricker et al., 1935) sp. nov. nom. rev. and "var. fuscans" of $X$. campestris pv. phaseoli (ex Smith, 1897) Dye 1978 as $X$. fuscans subsp. fuscans sp. nov., Syst. Appl. Microbiol. 28 (2005) 494-518.

[45] R. Schulze, S. Spring, R. Amann, I. Huber, W. Ludwig, K.-H. Schleifer, P. Kampfer, Genotypic diversity of Acidovorax strains isolated from activated sludge and description of Acidovorax defluvii sp. nov., Syst. Appl. Microbiol. 22 (1999) 205-214.

[46] W.Y. Song, A.J. Sechler, E. Hatziloukas, H.M. Kim, N.W. Schaad, Use of PCR for rapid identification of Acidovorax avenae and A. avenae subsp. citrulli., in: N.S. Iacobellis, et al. (Eds.), Pseudomonas syringae and related pathogens, Kluwer Academic Publishers, Dordrecht, 2003, pp. 531-544.

[47] W.Y. Song, H.M. Kim, C.Y. Hwang, N.W. Schaad, Detection of Acidovorax avenae ssp. avenae in rice seeds using BIO-PCR, J. Phytopathol. 152 (2004) 667-676.

[48] E. Stackebrandt, B.M. Goebel, Taxonomic note: a place for DNA/DNA reassociation and 16S rRNA sequence analysis in the present species definition in bacteriology, Int. J. Syst. Bacteriol. 44 (1994) 846-849.
[49] Y. Takikawa, Y. Ando, S. Hamaya, S. Tsuyumo, M. Goto, Identification of the pathogens responsible for bacteriosis of tea plants, Ann. Phytopathol. Soc. Jpn. 54 (1988) 224-228.

[50] T. Tominaga, Studies on the diseases of forage crops in Japan. II. Etiological studies on the bacterial diseases of forage crops in Japan,, Bull. Natl. Inst. Agric. Sci., Ser. (1971) 189-204.

[51] E. Van Zyl, P.L. Steyn, Taxonomy of the phytopathogenic Pseudomonas species belonging to Acidovorans rRNA complex, Syst. Appl. Microbiol. 14 (1991) 165-168.

[52] A.K. Vidaver, Synthetic and complex media for the rapid detection of fluorescence of phytopathogenic pseudomonads: effect of the carbon source, Appl. Microbiol. 15 (1967) 1523-1524.

[53] L.G. Wayne, D.J. Brenner, R.R. Colwell, P.A.D. Grimont, O. Kandler, M.I. Krichevsky, L.H. Moore, W.E.C. Moore, R.G.E. Murray, E. Stackebrandt, M.P. Starr, H.G. Truper, Report of the ad hoc committee on the reconciliation of approaches to bacterial systematics, Int. J. Syst. Bacteriol. 37 (1987) 463-464.

[54] A. Willems, E. Falsen, B. Pot, E. Jantzen, B. Hoste, P. Vandamme, M. Gillis, K. Kersters, J. De Ley, Acidovorax, a new genus for Pseudomonas facilis, Pseudomonas delafieldii, EF group 13, EF group 16, and several clinical isolates, with the species Acidovorax facilis comb. nov., Acidovorax delafieldii comb. nov., and Acidovorax temperans sp. nov., Int. J. Syst. Bacteriol. 40 (1990) 384-398.

[55] A. Willems, M. Goor, S. Thielemans, M. Gillis, K. Kersters, J. De Ley, Transfer of several phytopathogenic Pseudomonas species to Acidovorax as Acidovorax avenae subsp. avenae subsp. nov. comb. nov., Acidovorax avenae subsp.citrulli, Acidovorax avenae subsp. cattleyae, and Acidovorax konjaci, Int. J. Syst. Bacteriol. 42 (1992) 107-119.

[56] J. Young, G.S. Saddler, Y. Takikawa, S.H. De Boer, Names of plant pathogenic bacteria 1864-1995, Rev. Pl. Pathol. 75 (1995) 721-763. 